\title{
Tolvaptan Response Improves Overall Survival in Patients with Refractory Ascites: A Meta-Analysis
}

\author{
Ioannis Bellos ${ }^{a}$ Konstantinos Kontzoglou ${ }^{b}$ Amanda Psyrric \\ Vasilios Pergialiotis ${ }^{a}$ \\ a Laboratory of Experimental Surgery and Surgical Research N.S. Christeas, Athens University Medical School,

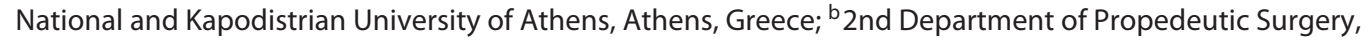 \\ "Laikon" General Hospital, National and Kapodistrian University of Athens, Athens, Greece; 'Division of Oncology, \\ 2nd Department of Internal Medicine, Attikon University Hospital, Athens, Greece
}

\section{Keywords}

Tolvaptan · Response · Ascites · Cirrhosis · Meta-analysis

\begin{abstract}
Background and Aims: Refractory ascites represents a significant complication of decompensated cirrhosis, associated with increased mortality rates. The aim of this meta-analysis was to evaluate whether response to treatment with tolvaptan is associated with improved overall survival in cirrhotic patients with refractory ascites. Methods: Medline, Scopus, Cochrane Central Register of Controlled Trials, Clinicaltrials.gov, and Google Scholar databases were systematically searched from inception to April 11, 2019. All studies that assessed the overall survival of patients with ascites depending on their response to tolvaptan were held eligible. Results: Nine studies were included, with a total of 736 patients with cirrhosis and ascites. Response to tolvaptan was estimated to be linked to significantly improved overall survival (hazard ratio [HR] 0.42, 95\% Cl [0.31-0.58]). Subgroup analysis indicated that the same outcome was present when tolvaptan responsiveness was defined either as effective body weight loss (HR 0.44, 95\% Cl [0.30-0.63] or as effective
\end{abstract}

sodium restoration ( $\mathrm{HR} 0.35,95 \% \mathrm{Cl}$ [0.20-0.61]. Sensitivity analysis suggested that the presence of hepatocellular carcinoma, the sample size, and the quality of the studies did not significantly affect the overall result of the meta-analysis. Conclusions: The outcomes of the meta-analysis support the prognostic role of tolvaptan response in patients with cirrhosis and refractory ascites, as it was shown to lead to significantly improved overall survival. These findings should be confirmed by future large-scale studies, while efficient biomarkers should be identified in order to accurately predict response to tolvaptan and discriminate patients that would benefit from its administration.

(c) 2019 S. Karger AG, Basel

\section{Introduction}

Ascites represents a major complication of decompensated liver cirrhosis, associated with increased morbidity, poor quality of life, and adverse long-term outcomes [1]. The pathophysiology of ascites formation is multifactorial and is based on the presence of hypoalbuminemia, portal hypertension, and splanchnic vasodilation [2].

\section{KARGER}

(c) 2019 S. Karger AG, Basel

karger@karger.com

www.karger.com/ddi
Ioannis Bellos, $\mathrm{MD}$

Laboratory of Experimental Surgery and Surgical Research N.S. Christeas Athens University Medical School, National and Kapodistrian University of Athens 15B, Ag. Thoma street, GR-115 27 Athens (Greece)

E-Mail bellosg@ windowslive.com 
Subsequently, sympathetic nervous system and vasoconstrictor factors, especially arginine-vasopressin and renin-angiotensin-aldosterone axis are homeostatically activated, leading to sodium retention and impaired freewater excretion [3]. Conventional management mainly includes a salt-restricted diet in conjunction with the administration of loop diuretics and spironolactone [4]; however, refractory ascites develops in up to $10 \%$ of patients [5], as a consequence of a lack of response despite intensive diuretic therapy or the inability to reach effective doses due to adverse effects, such as renal impairment, electrolyte disturbances, and hepatic encephalopathy [6].

Tolvaptan is a novel, nonpeptide, orally administered, selective vasopressin $\mathrm{V}_{2}$-receptor antagonist, which downregulates the expression of aquaporin-2 in the collecting duct. It exerts its action by inhibiting water reabsorption, leading to aquaresis without affecting electrolyte excretion [7]. The main clinical indication of tolvaptan is the correction of euvolemic and hypervolemic hyponatremia [8], although growing evidence also suggests its efficacy in the management of fluid retention in the setting of acute heart failure [9] and cardiac surgery [10], since it is able to improve congestive symptoms without compromising renal function.

Recent research has proposed the promising role of tolvaptan as an add-on treatment in patients with hepatic ascites resistant to conventional diuretics, as it is able to decrease body weight, alleviate edema [6], and ameliorate long-term outcomes [11]. Nevertheless, its potency varies widely, since not all patients benefit the same from its administration [12]. As a result, several observational studies have recently evaluated the clinical significance of tolvaptan responsiveness, although its exact value as a prognostic marker remains still controversial. The aim of the present meta-analysis is to accumulate current evidence in the field and clarify whether response to tolvaptan treatment is associated with improved overall survival in liver cirrhotic patients with refractory ascites.

\section{Materials and Methods}

\section{Study Design}

The present meta-analysis was designed according to the Preferred Reporting Items for Systematic Reviews and Meta-Analyses guidelines [13]. Selection criteria were predetermined. Specifically, studies were deemed eligible if they compared overall survival among liver cirrhotic patients with ascites characterized as tolvaptan responders and nonresponders. Study selection was performed in 3 consecutive stages. First, the titles and/or abstracts of all electronic articles were screened to assess their eligibility. The articles presumed to meet the selection criteria were retrieved as full-texts. Finally, all observational studies (both prospective and retrospective) that reported the outcome of interest were included. Case reports, small case series ( $<10$ patients), conference abstracts, review articles, meta-analyses, and animal studies were excluded. Any discrepancies regarding retrieval of articles and/or statistical analyses were resolved by the consensus of all authors.

\section{Literature Search and Data Collection}

Literature search was primarily conducted using the Medline (1966-2019), Scopus (2004-2019), Cochrane Central Register of Controlled Trials (1999-2019), and Clinicaltrials.gov (2008-2019) databases. Google Scholar (2004-2019) database and the reference list of the included studies ("snowball" method) were also searched in order to identify potential eligible articles. The date of the last search was set at April 8, 2019. The search strategy included the following algorithm: "(tolvaptan OR vaptan OR [(adh OR avp OR vasopressin) AND antagonist]) AND (cirrhosis OR ascites OR hepatic edema)" and is schematically presented in the Systematic Reviews and Meta-Analyses flowchart (Fig. 1).

\section{Investigated Indices}

The extracted data from each study were planned to be the following: name of first author, year of publication, sample size, study design, inclusion and exclusion criteria, tolvaptan dose, concomitant medications, definition to tolvaptan response, mean age, Child-Pugh score, proportion of patients with hepatitis $\mathrm{C}$ or hepatocellular carcinoma, blood urea nitrogen, serum sodium, and albumin levels. The outcome of interest was overall survival of cirrhotic patients with ascites depending on their response to the treatment with tolvaptan.

\section{Quality Assessment}

The quality of all observational studies was judged with the Risk Of Bias In Non-randomized Studies (ROBINS-I) assessment tool [14], which investigates the potential presence of bias by evaluating studies on the grounds of confounding, selection, classification, deviation from intended intervention, missing data, measurement, and reporting of the outcomes. The tool was independently implemented by 2 reviewers, while any disagreements were resolved through the consensus of all authors.

\section{Statistical Analysis}

The statistical meta-analysis was performed using the Review Manager 5.3 software (Copenhagen: The Nordic Cochrane Centre, The Cochrane Collaboration, 2011). Confidence intervals were set at $95 \%$. The inconsistency index $\left(I^{2}\right)$ was used as a measure of interstudy heterogeneity [15]. Hazard ratio (HR) was chosen as the most appropriate measure of the survival outcomes, as it takes into consideration both the number and the timing of events [16]. When HR was not reported, it was estimated by reconstructing the Kaplan-Meier curve, taking into account the minimum and maximum follow-up period [17] or the number of patients at risk during particular time intervals [18]. A random effects model was implemented to calculate pooled estimates of HR along with the $95 \%$ $\mathrm{CI}$, due to the significant heterogeneity of the methodological characteristics of the included studies.

Subgroup analysis was conducted based on the definition of tolvaptan response (body weight loss or sodium restoration). As sensitivity analysis, the effect of tolvaptan response on overall sur- 


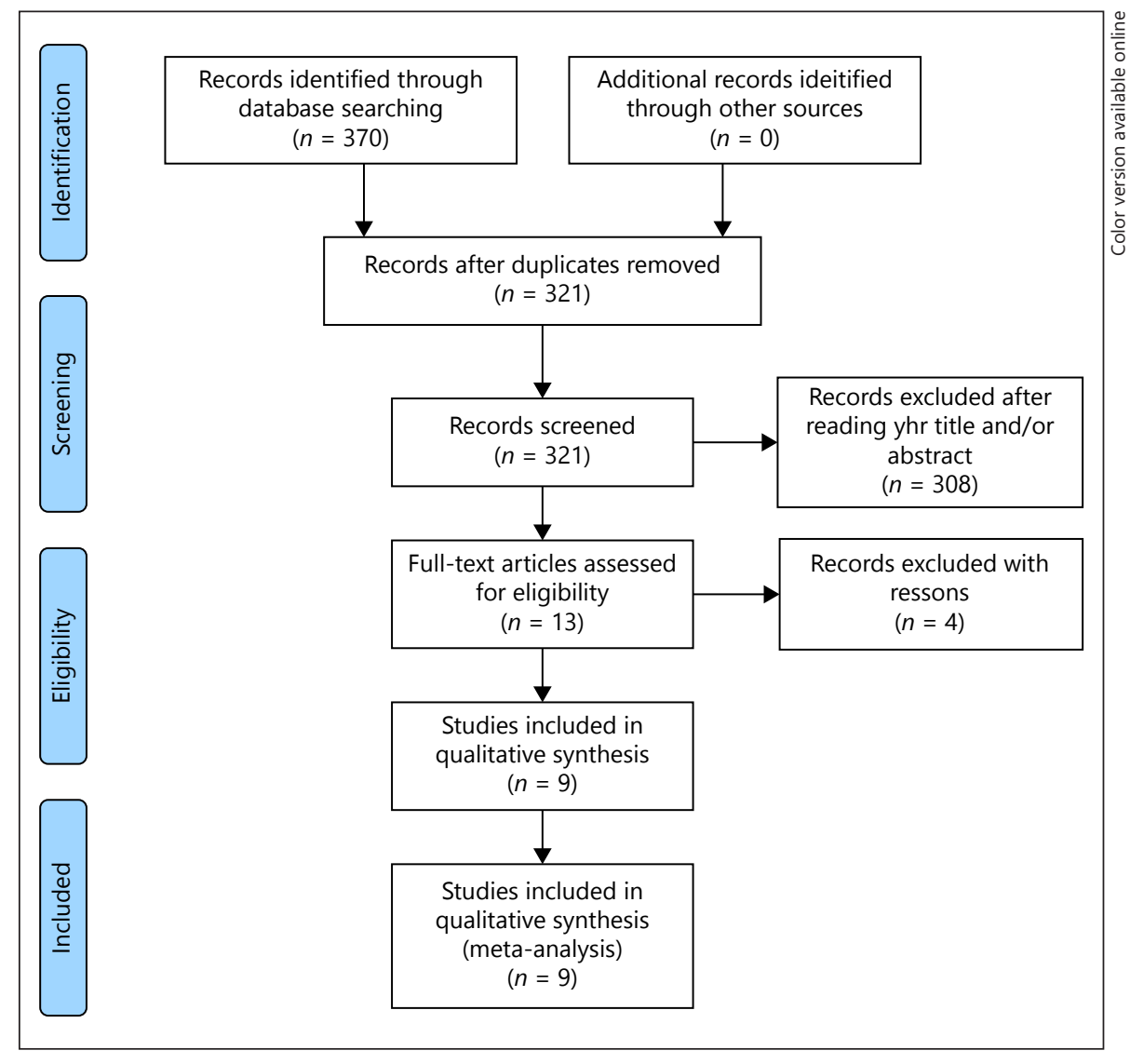

Fig. 1. Search plot diagram.

vival was separately calculated for patients without hepatocellular carcinoma, as well as for studies with large sample size ( $>80$ patients) and low risk of bias, as assessed by the ROBINS-I tool. Moreover, leave-one-out analysis was performed in order to evaluate the influence of individual studies on the overall outcome. To achieve this, one study was sequentially omitted at a time and thus its contribution to the meta-analytic result was assessed.

\section{Results}

\section{Included Studies}

Nine studies [19-27] were included in the analysis, with a total of 736 patients. Among them, 451 patients presented clinical response to tolvaptan therapy, while the rest 285 were judged as nonresponders. The methodological characteristics of the included studies (study design, eligibility criteria, tolvaptan dosage, concomitant medications, and definition of response) are described in Table 1. The analysis was based exclusively on cohort studies, with one of them presenting a prospective design. The presence of hyponatremia was a prerequisite for 2 studies $[22,26]$, while cases with hepatocellular carcinoma were included in 7 studies. The most common tolvaptan dose was $7.5 \mathrm{mg} / \mathrm{day}$ (range $3.5-30 \mathrm{mg} /$ day). Conventional treatment included sodium restriction, administration of furosemide and spironolactone, albumin infusion, or the combination of the above. Tolvaptan response was defined as effective body weight loss in 7 studies, while in the rest 2 as effective sodium restoration $[22,26]$. The patients' baseline characteristics (age, Child-Pugh score, presence of hepatitis C or hepatocellular carcinoma, blood urea nitrogen, serum sodium, and albumin) are presented in Table 2. No significant differences were noted among the 2 groups concerning the majority of the examined parameters.

\section{Excluded Studies}

Four studies [12, 28, 29, 30] were excluded after reading the full text. Specifically, one of them did not directly compare the survival among tolvaptan responders and nonresponders [30], while 2 studies investigated predictive factors of response to tolvaptan without evaluating its effect on overall survival rates [12, 29]. In addition, one study was excluded as a partial duplicate of another study already included in the analysis [28]. 
Table 1. Study characteristics

\begin{tabular}{|c|c|c|c|c|c|c|}
\hline Author, year & $\begin{array}{l}\text { Study } \\
\text { design }\end{array}$ & Inclusion criteria & Exclusion criteria & Tolvaptan dose & Concomitant medications & $\begin{array}{l}\text { Response } \\
\text { definition }\end{array}$ \\
\hline $\begin{array}{l}\text { Kida [27], } \\
2019\end{array}$ & RC & Hepatic ascites & Hepatic malignancy & $\begin{array}{l}3.75 \mathrm{mg} \text {, increased to } \\
7.5 \mathrm{mg} / \text { day if insufficient } \\
\text { effect on day } 3\end{array}$ & $\begin{array}{l}\text { Sodium restriction, } \\
\text { albumin, furosemide, } \\
\text { spironolactone }\end{array}$ & $\begin{array}{l}\text { Body weight } \\
\text { loss } \geq 1.5 \mathrm{~kg} \\
\text { within 1st week }\end{array}$ \\
\hline $\begin{array}{l}\text { Wang } \\
\text { et al. [26], } 2018\end{array}$ & PC & $\begin{array}{l}\text { Hepatic ascites } \\
\text { and hyponatremia }\end{array}$ & $\begin{array}{l}\text { Age }<18 \text { or }>75 \text { years, hepatic } \\
\text { malignancy, type } 1 \text { hepatorenal } \\
\text { syndrome, any neurological } \\
\text { disorder, history of stroke, } \\
\text { uncontrolled DM, HF, anuria, } \\
\text { hepatic encephalopathy } \geq \text { grade } 2\end{array}$ & $7.5-30 \mathrm{mg} /$ day & $\begin{array}{l}\text { Sodium restriction, } \\
\text { furosemide, } \\
\text { spironolactone }\end{array}$ & $\begin{array}{l}\text { Serum sodium } \\
\text { between } 135 \\
\text { and } 155 \mathrm{mEq} / \mathrm{L}\end{array}$ \\
\hline $\begin{array}{l}\text { Tajiri } \\
\text { et al. [25], } 2018\end{array}$ & $\mathrm{RC}$ & $\begin{array}{l}\text { Refractory } \\
\text { hepatic ascites }\end{array}$ & $\begin{array}{l}\text { Temporary ascites, HF, ADPKD, } \\
\text { carcinomatous peritonitis }\end{array}$ & $3.75-7.5 \mathrm{mg} /$ day & $\begin{array}{l}\text { Sodium restriction, } \\
\text { furosemide, spironolactone }\end{array}$ & $\begin{array}{l}\text { Body weight } \\
\text { loss } \geq 2 \mathrm{~kg} \\
\text { within } 1 \text { st week }\end{array}$ \\
\hline $\begin{array}{l}\text { Arase } \\
\text { et al. [24], } 2018\end{array}$ & $\mathrm{RC}$ & $\begin{array}{l}\text { Refractory } \\
\text { hepatic ascites }\end{array}$ & $\begin{array}{l}\text { SBP, hepatic encephalopathy } \\
\geq \text { grade } 2 \text {, albumin infusion } \\
\text { within } 7 \text { days }\end{array}$ & $7.5 \mathrm{mg} /$ day & Furosemide, spironolactone & $\begin{array}{l}\text { Body weight } \\
\text { loss } \geq 1.5 \mathrm{~kg} \\
\text { within 1st week }\end{array}$ \\
\hline $\begin{array}{l}\text { Tahara } \\
\text { et al. [23], } 2017\end{array}$ & $\mathrm{RC}$ & $\begin{array}{l}\text { Refractory } \\
\text { hepatic ascites }\end{array}$ & $\begin{array}{l}\text { Drainage by paracentesis within } \\
7 \text { days, warfarin use }\end{array}$ & $7.5 \mathrm{mg} /$ day & $\begin{array}{l}\text { Sodium restriction, } \\
\text { furosemide, spironolactone }\end{array}$ & $\begin{array}{l}\text { Body weight } \\
\text { loss } \geq 2 \mathrm{~kg} \\
\text { within 1st week }\end{array}$ \\
\hline $\begin{array}{l}\text { Kogiso } \\
\text { et al. [22], } 2017\end{array}$ & RC & $\begin{array}{l}\text { Hepatic ascites } \\
\text { and hyponatremia }\end{array}$ & $\begin{array}{l}\text { Severe renal dysfunction, hepatic } \\
\text { encephalopathy } \geq \text { grade } 2\end{array}$ & $3.75 \mathrm{mg} /$ day & $\begin{array}{l}\text { Sodium restriction, } \\
\text { furosemide, spironolactone }\end{array}$ & $\begin{array}{l}\text { Serum sodium } \\
\geq 135 \mathrm{mEq} / \mathrm{L} \\
\text { within } 1 \text { st week }\end{array}$ \\
\hline $\begin{array}{l}\text { Atsukawa } \\
\text { et al. [21], } 2018\end{array}$ & RC & $\begin{array}{l}\text { Refractory hepatic } \\
\text { ascites, pleural } \\
\text { effusion or } \\
\text { lower-limb edema }\end{array}$ & $\begin{array}{l}\text { Age }<20 \text { or }>90 \text { years, type } 1 \\
\text { hepatorenal syndrome, hepatic } \\
\text { encephalopathy } \geq \text { grade } 2 \text {, varices } \\
\text { requiring treatments, serum } \\
\text { sodium }>147 \mathrm{mEq} / \mathrm{L}\end{array}$ & $7.5 \mathrm{mg} /$ day & $\begin{array}{l}\text { Sodium restriction, } \\
\text { furosemide, spironolactone }\end{array}$ & $\begin{array}{l}\text { Body weight } \\
\text { loss } \geq 1.5 \mathrm{~kg} \\
\text { within 1st week }\end{array}$ \\
\hline $\begin{array}{l}\text { Yamada } \\
\text { et al. [20], } 2016\end{array}$ & $\mathrm{RC}$ & $\begin{array}{l}\text { Refractory hepatic } \\
\text { ascites or pleural } \\
\text { effusion }\end{array}$ & $\begin{array}{l}\text { Age }<20 \text { or }>80 \text { years, SBP, } \\
\text { hepatic encephalopathy, } \\
\text { hemodialysis }\end{array}$ & $3.75-7.5 \mathrm{mg} /$ day & $\begin{array}{l}\text { Sodium restriction, } \\
\text { albumin, furosemide, } \\
\text { spironolactone }\end{array}$ & $\begin{array}{l}\text { Body weight } \\
\text { loss } \geq 2 \mathrm{~kg} \\
\text { within 1st week }\end{array}$ \\
\hline $\begin{array}{l}\text { Iwamoto } \\
\text { et al. [19], } 2016\end{array}$ & $\mathrm{RC}$ & $\begin{array}{l}\text { Refractory } \\
\text { hepatic ascites }\end{array}$ & NR & $\begin{array}{l}3.75 \mathrm{mg} \text {, increased to } \\
7.5 \mathrm{mg} / \text { day if insufficient } \\
\text { effect on day } 3\end{array}$ & Furosemide, spironolactone & $\begin{array}{l}\text { Body weight } \\
\text { loss } \geq 2 \mathrm{~kg} \\
\text { within } 1 \text { st week }\end{array}$ \\
\hline
\end{tabular}

RC, retrospective cohort; PC, prospective cohort; DM, diabetes mellitus; HF, heart failure; ADPKD, Autosomal Dominant Polycystic Kidney Disease; SBP, spontaneous bacterial peritonitis; NR, not reported.

\section{Quality Assessment}

The outcomes of ROBINS-I tool are presented in Table 3. The overall bias was judged to be low in 5 studies and moderate in the rest 4 . It should be noted that risk of bias mainly came from the domain of missing data, due to lack of firm evidence that no discrepancies of the follow-up periods existed depending on tolvaptan response. Furthermore, confounding may have contributed to the overall bias in studies where nonresponders presented higher Child-Pugh scores or impaired renal function.

\section{Outcomes}

Response to tolvaptan treatment was associated with improved overall survival (HR 0.42, 95\% CI [0.31-0.58], $\left.I^{2}=39 \%\right)$. Subgroup analysis indicated that the same effect was present when response was defined as effective body weight loss (HR 0.44, 95\% CI [0.30-0.63], $I^{2}=$
$48 \%$ ) or as effective sodium restoration (HR $0.35,95 \%$ CI [0.20-0.61], $I^{2}=0 \%$; Fig. 2). More specifically, a survival benefit was observed when effective body weight loss was defined either as weight loss $\geq 1.5 \mathrm{~kg}$ within $1 \mathrm{st}$ week (HR 0.36, 95\% CI [0.15-0.85], $I^{2}=78 \%$ ) or as weight loss $\geq 2 \mathrm{~kg}$ within 1st week (HR $0.44,95 \%$ CI $\left.[0.31-0.63], I^{2}=0 \%\right)$. Sensitivity analysis revealed that tolvaptan response also lead to better overall survival when patients without hepatocellular carcinoma were separately examined (HR 0.25, 95\% CI [0.11-0.55], 3 studies). Moreover, the same outcome was evident in studies with large ( $>80$ patients) sample size (HR 0.37, 95\% CI [0.21-0.66], 4 studies), as well as in studies with low risk of bias (HR 0.38, 95\% CI [0.25-0.57], 5 studies). Leave-one-out analysis suggested that the results remain stable, since the overall outcome was significantly affected by no single study (Table 4 ). 
Table 2. Patients' baseline characteristics

\begin{tabular}{|c|c|c|c|c|c|c|c|c|}
\hline $\begin{array}{l}\text { Author, } \\
\text { year }\end{array}$ & $\begin{array}{l}\text { Patients } \\
\text { number }\end{array}$ & Age, years & $\begin{array}{l}\text { Child-Pugh } \\
\text { score }\end{array}$ & $\mathrm{HCC}$ & $\mathrm{HCV}$ & BUN, mg/dL & $\begin{array}{l}\text { Serum } \\
\text { sodium, } \mathrm{mEq} / \mathrm{L}\end{array}$ & $\begin{array}{l}\text { Serum } \\
\text { albumin, g/dL }\end{array}$ \\
\hline \multicolumn{9}{|c|}{ Responders vs. non-responders } \\
\hline $\begin{array}{l}\text { Kida [27], } \\
2019\end{array}$ & 53 vs. 33 & $\begin{array}{l}75.2 \pm 14.1 \text { vs. } \\
78 \pm 14.1\end{array}$ & $\begin{array}{l}10.2 \pm 1.7 \text { vs. } \\
10 \pm 1.2\end{array}$ & - & $\begin{array}{l}11 \mathrm{vs.} \\
7\end{array}$ & $\begin{array}{l}20.2 \pm 13.5 \text { vs. } \\
37.3 \pm 29.3\end{array}$ & $\begin{array}{l}137 \pm 6 \text { vs. } \\
135 \pm 6\end{array}$ & $\begin{array}{l}2.6 \pm 0.6 \text { vs. } \\
2.5 \pm 0.6\end{array}$ \\
\hline $\begin{array}{l}\text { Wang et al. } \\
{[26], 2018}\end{array}$ & 44 vs. 25 & $54.6 \pm 8.58$ & NR & - & 4 & $14.8 \pm 2.2$ & $130 \pm 4$ & NR \\
\hline $\begin{array}{l}\text { Tajiri et al. } \\
\text { [25], } 2018\end{array}$ & 37 vs. 37 & $68(35-90)$ & $\begin{array}{l}\text { A: } 0, B: 29 \\
\text { C: } 45\end{array}$ & 25 & 20 & $23.5(6-150)$ & $135(118-142)$ & $2.35(1.2-3.7)$ \\
\hline $\begin{array}{l}\text { Arase et al. } \\
{[24], 2018}\end{array}$ & 27 vs. 16 & $68(39-84)$ & $\begin{array}{l}\text { A: } 0, B: 20 \\
C: 23\end{array}$ & 9 & 21 & $23(7-92)$ & $137(118-145)$ & $2.2(1.4-3.1)$ \\
\hline $\begin{array}{l}\text { Tahara et al. } \\
{[23], 2017}\end{array}$ & 45 vs. 20 & $71.5 \pm 9.1$ & $\begin{array}{l}\text { A: } 0, B: 28, \\
\text { C: } 37\end{array}$ & 28 & 40 & NR & $137.0 \pm 4.7$ & $2.3 \pm 0.5$ \\
\hline $\begin{array}{l}\text { Kogiso et al. } \\
{[22], 2017}\end{array}$ & 65 vs. 18 & $\begin{array}{l}64(22-90) \text { vs. } \\
61(31-84)\end{array}$ & $\begin{array}{l}10(7-14) \text { vs. } \\
11(8-13)\end{array}$ & $\begin{array}{l}22 \text { vs. } \\
6\end{array}$ & NR & $\begin{array}{l}23.1(5.5-78.7) \text { vs. } \\
22.5(5.8-64.3)\end{array}$ & NR & $\begin{array}{l}2.5(1.9-4.2) \text { vs. } \\
2.4(1.8-3.2)\end{array}$ \\
\hline $\begin{array}{l}\text { Atsukawa et al. } \\
{[21], 2018}\end{array}$ & 116 vs. 94 & $\begin{array}{l}67(41-85) \text { vs. } \\
65(40-89)\end{array}$ & $\begin{array}{l}\text { A: } 1 \text { vs. } 4, \\
\text { B: } 49 \text { vs. } 41 \\
\text { C: } 66 \text { vs. } 49\end{array}$ & $\begin{array}{l}34 \text { vs. } \\
30\end{array}$ & NR & $\begin{array}{l}18.8(6.0-94.0) \text { vs. } \\
21.9(5.4-81.8)^{*}\end{array}$ & $\begin{array}{l}136(118-146) \text { vs. } \\
136(115-147)\end{array}$ & $\begin{array}{l}2.6(1.7-4.0) \text { vs. } \\
2.6(1.6-4.2)\end{array}$ \\
\hline $\begin{array}{l}\text { Yamada et al. } \\
{[20], 2016}\end{array}$ & 48 vs. 32 & $\begin{array}{l}73(62-79) \text { vs. } \\
68(63-75)\end{array}$ & C: 15 vs. $24^{*}$ & $\begin{array}{l}31 \text { vs. } \\
24\end{array}$ & $\begin{array}{l}31 \text { vs. } \\
14\end{array}$ & NR & $\begin{array}{l}136(132-139) \text { vs. } \\
133(130-136)\end{array}$ & $\begin{array}{l}2.8(2.5-3.2) \text { vs. } \\
2.8(2.4-3.0)\end{array}$ \\
\hline $\begin{array}{l}\text { Iwamoto et al. } \\
{[19], 2016}\end{array}$ & 16 vs. 10 & $\begin{array}{l}71.6 \pm 9 \text { vs. } \\
71.9 \pm 6.2\end{array}$ & $\begin{array}{l}9.8 \pm 1.9 \text { vs. } \\
9.7 \pm 1.1\end{array}$ & 17 & 20 & $\begin{array}{l}24.2 \pm 14.4 \text { vs. } \\
36.1 \pm 11.4^{*}\end{array}$ & $\begin{array}{l}136.6 \pm 3.6 \text { vs. } \\
134.4 \pm 5.7\end{array}$ & $\begin{array}{l}2.6 \pm 0.5 \text { vs. } \\
2.5 \pm 0.4\end{array}$ \\
\hline
\end{tabular}

$* p$ value $<0.05$.

HCC, hepatocellular carcinoma; HCV, hepatitis C virus; BUN, blood urea nitrogen; NR, not reported.

\section{Discussion}

Refractory ascites and hyponatremia constitute major complications of liver cirrhosis, since they are associated with increased morbidity and mortality, as well as with poor quality of life [31]. Vaptans have been proposed as promising tools for the management of cirrhotic patients, since they are able to promote free-water excretion, alleviate edema, and restore serum sodium levels. Although no clinical benefit was shown from the use of satavaptan [32], growing evidence supports that treatment with tolvaptan represents a safe and efficient option for patients with refractory ascites. Specifically, tolvaptan has been suggested to effectively reduce body weight, limit the required doses of diuretics, and elevate serum sodium concentration, without significantly increasing the rate of serious adverse effects $[33,34]$.

The findings of the present meta-analysis indicate that short-term response to tolvaptan administration is associated with significantly improved overall survival in patients with liver cirrhosis and refractory ascites or hyponatremia. This effect was independent of the presence of hepatocellular carcinoma or the definition of tolvaptan response, suggesting its long-term prognostic value in diuretic-resistant ascites. Interestingly, extended survival was even observed in responders with severe chronic kidney disease, as tolvaptan was able to increase urine volume without compromising renal function [24]. Much research interest has been devoted to identify potential markers in order to predict which patients would benefit from the administration of tolvaptan. Specifically, the most promising results exist regarding the use of urine osmolality, sodium excretion [35], and aquaporin 2 levels [36], although the optimal predictive model remains still under investigation.

\section{Strengths and Limitations of the Study}

The present study accumulated for the first time current literature knowledge regarding the possible prognostic role of tolvaptan response in patients with refractory ascites. This was accomplished by systematically searching 5 independent literature databases and by applying no date or language restriction. In contrast to previous meta-analyses in the field $[37,38]$, the present meta-analysis focused on survival outcomes and examined 
Table 3. Outcomes of the quality assessment. The overall risk of bias was evaluated to be low to moderate

\begin{tabular}{|c|c|c|c|c|c|c|}
\hline \multicolumn{7}{|l|}{ ROBINS-I tool } \\
\hline Kida [27], 2019 & Low & Low & Moderate & Low & Low & Low \\
\hline $\begin{array}{l}\text { Wang } \\
\text { et al. [26], } 2018\end{array}$ & Moderate & Moderate & Moderate & Low & Low & Moderate \\
\hline $\begin{array}{l}\text { Arase } \\
\text { et al. [24], } 2018\end{array}$ & Low & Low & Moderate & Low & Low & Low \\
\hline $\begin{array}{l}\text { Tahara } \\
\text { et al. [23], } 2017\end{array}$ & Low & Low & Moderate & Low & Low & Low \\
\hline $\begin{array}{l}\text { Yamada } \\
\text { et al. [20], } 2016\end{array}$ & Low & Low & Moderate & Low & Low & Low \\
\hline $\begin{array}{l}\text { Iwamoto } \\
\text { et al. [19], } 2019\end{array}$ & Moderate & Moderate & Moderate & Low & Low & Moderate \\
\hline
\end{tabular}

ROBINS-I, Risk Of Bias In Non-randomized Studies of Interventions.

the effect of tolvaptan response on patients' long-term prognosis. In order to properly analyze time-to-event data, HRs were estimated for each study and were pooled together to provide the meta-analytic estimate. Moreover, subgroup and sensitivity analyses were conducted, taking into account the most important confounding factors that may have remarkably altered the outcomes of the analysis.

Nevertheless, the findings of the meta-analysis were based on 9 studies, including a moderate number of patients. More specifically, the interpretation of the study outcomes may be complicated by the existing interstudy heterogeneity. Definition of tolvaptan response was recognized as the most important confounding factor; therefore, subgroup analysis was performed, indicating that overall survival was improved irrespective of whether response was defined as sodium normalization, weight loss $\geq 1.5$ or $\geq 2 \mathrm{~kg}$ during the 1 st week of treatment. Furthermore, the design of the majority of the studies was retrospective and thus bias due to missing data could not be safely excluded. However, sensitivity analysis indicated that the outcomes of the meta-analysis were not affected when studies with low risk of bias were separately examined. It is also important to state that all studies were con- ducted in Asian populations, a fact that although enhances their comparability, may limit the generalizability of the results.

\section{Implications for Current Clinical Practice and Future \\ Research}

The outcomes of the present meta-analysis suggest that patients with refractory ascites responding to tolvaptan treatment present significantly improved overall survival rates. As a result, short-term clinical response, defined either as effective body weight loss or sodium elevation, represents an important prognostic factor, as it is associated with better long-term outcomes. However, it should be noted that these findings are derived from observational studies and thus warrant confirmation by large-scale randomized controlled trials, in order to limit the possibility of bias due to confounding and patient selection. Specifically, future studies evaluating the potency of tolvaptan should not only assess its diuretic effects but they should also focus on hard outcomes, such as hospitalization stay and mortality rates. Quality of life should also be taken into consideration, as it constitutes a significant aspect of cirrhotic patients' management. Finally, sincehepatotoxicity represents the main concern about the wide use of tolvap- 


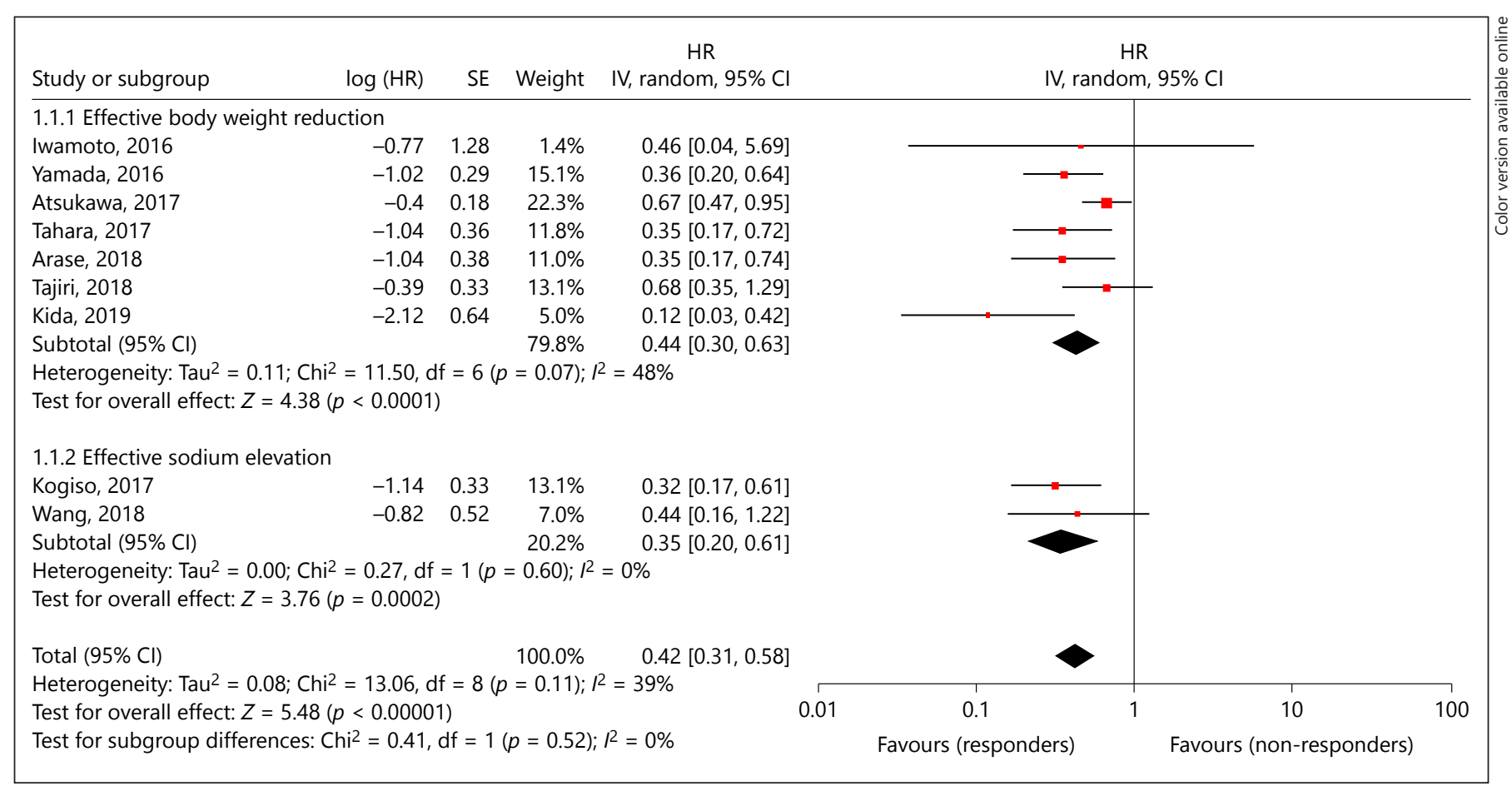

Fig. 2. Forest plot illustrating the overall survival benefit of tolvaptan responders compared to nonresponders. HR, hazard ratio.

Table 4. Outcomes of the leave-one-out analysis

\begin{tabular}{llllll}
\hline Omitted study & HR & 95\% CI & $p$ value & \multicolumn{2}{c}{ Heterogeneity } \\
\cline { 4 - 5 } & & & & $I^{2}, \%$ & $p$ value \\
\hline Kida [27], 2019 & 0.47 & $0.36-0.61$ & $<0.001$ & 17 & 0.30 \\
Wang et al. [26], 2018 & 0.42 & $0.30-0.59$ & $<0.001$ & 46 & 0.07 \\
Tajiri et al. [25], 2018 & 0.39 & $0.28-0.55$ & $<0.001$ & 40 & 0.11 \\
Arase et al. [24], 2018 & 0.43 & $0.31-0.60$ & $<0.001$ & 44 & 0.09 \\
Tahara et al. [23], 2017 & 0.43 & $0.31-0.61$ & $<0.001$ & 43 & 0.09 \\
Kogiso et al. [22], 2017 & 0.44 & $0.32-0.62$ & $<0.001$ & 39 & 0.12 \\
Atsukawa et al. [21], 2018 & 0.38 & $0.29-0.50$ & $<0.001$ & 0 & 0.45 \\
Yamada et al. [20], 2016 & 0.43 & $0.30-0.61$ & $<0.001$ & 42 & 0.10 \\
Iwamoto et al. [19], 2019 & 0.42 & $0.30-0.58$ & $<0.001$ & 46 & 0.07 \\
Overall & 0.42 & $0.31-0.58$ & $<0.001$ & 39 & 0.11 \\
\hline
\end{tabular}

HR, hazard ratio; $I^{2}$, inconsistency index.

tan in cirrhotic patients [39], it is important to develop accurate screening tests that would identify tolvaptan nonresponders, in order to limit its unnecessary administration. More specifically, it has been shown that tolvaptan response may be associated with body weight, blood urea nitrogen, serum creatinine, $\mathrm{C}$-reactive protein, and serum sodium levels, while no predictive value has been estimat- ed for patients' age, gender, MELD-Na score, or presence of hepatocellular carcinoma [40]. In addition, similarly to prediction of hepatorenal treatment response [41], urinary sodium has been proposed as a promising marker of tolvaptan response [35], although limited evidence is currently available to draw safe conclusions about its exact role. As a result, future large-scale studies are needed in 
order to construct a combined model effectively discriminating the population in which the benefits of tolvaptan therapy would outweigh the risks of liver toxicity.

\section{Conclusions}

The present meta-analysis supports the prognostic role of tolvaptan response, since it is associated with significantly improved overall survival in cirrhotic patients with refractory ascites. This effect was independent of response definition or presence of hepatocellular carcinoma. Future large-scale trials should verify these outcomes, as well as to identify the optimal markers to predict the effectiveness of tolvaptan. Patients' comorbidities and concomitant medications should be taken into account in order to limit the possibility of confounding.

\section{Key Points}

- Refractory ascites represents a major complication of cirrhosis leading to increased morbidity and mortality.

- Tolvaptan has been proposed as an add-on treatment in order to alleviate edema and decrease body weight.

- The present meta-analysis suggests that response to tolvaptan is linked to improved overall survival.
- This association was independent of response definition and presence of hepatocellular carcinoma.

- Future studies should identify efficient markers to predict tolvaptan response.

\section{Acknowledgment}

None.

\section{Statement of Ethics}

No ethical approval was required. The present systematic review and meta-analysis is based on aggregated data that were retrieved from studies already retrieved. We did not collect individual patient data and did not have direct contact with patients included.

\section{Disclosure Statement}

The authors have no conflicts of interest to declare.

\section{Funding Sources}

There is no funding source to declare.

\section{References}

1 Ginés P, Quintero E, Arroyo V, Terés J, Bruguera $\mathrm{M}$, Rimola $\mathrm{A}$, et al.: Compensated cirrhosis: natural history and prognostic factors. Hepatology. 1987 Jan-Feb;7(1):122-8.

2 Di Pascoli M, Sacerdoti D, Pontisso P, Angeli P, Bolognesi M. Molecular Mechanisms Leading to Splanchnic Vasodilation in Liver Cirrhosis. J Vasc Res. 2017;54(2):92-9.

3 Pose E, Cardenas A. Translating Our Current Understanding of Ascites Management into New Therapies for Patients with Cirrhosis and Fluid Retention. Dig Dis. 2017;35(4): 402-10.

4 Ginès $\mathrm{P}$, Cárdenas $\mathrm{A}$, Arroyo $\mathrm{V}$, Rodés J. Management of cirrhosis and ascites. N Engl J Med. 2004 Apr;350(16):1646-54.

5 Cárdenas A, Ginès P. Management of refractory ascites. Clin Gastroenterol Hepatol. 2005 Dec;3(12):1187-91.

6 Taki Y, Kanazawa H, Narahara Y, Itokawa N, Kondo C, Fukuda T, et al. Predictive factors for improvement of ascites after transjugular intrahepatic portosystemic shunt in patients with refractory ascites. Hepatol Res. 2014 Aug;44(8):871-7.

7 Bhatt PR, McNeely EB, Lin TE, Adams KF Jr, Patterson JH. Review of Tolvaptan's Pharma-

Tolvaptan Response in Refractory Ascites cokinetic and Pharmacodynamic Properties and Drug Interactions. J Clin Med. 2014 Nov; 3(4):1276-90.

8 Li B, Fang D, Qian C, Feng H, Wang Y. The Efficacy and Safety of Tolvaptan in Patients with Hyponatremia: A Meta-Analysis of Randomized Controlled Trials. Clin Drug Investig. 2017 Apr;37(4):327-42.

9 Wang C, Xiong B, Cai L. Effects of Tolvaptan in patients with acute heart failure: a systematic review and meta-analysis. BMC Cardiovasc Disord. 2017 Jun;17(1):164.

10 Bellos I, Iliopoulos DC, Perrea DN. The Role of Tolvaptan Administration After Cardiac Surgery: A Meta-Analysis. J Cardiothorac Vasc Anesth. 2019 Aug;33(8):2170-9.

11 Hayashi M, Abe K, Fujita M, Okai K, Takahashi A, Ohira H. Association between the Serum Sodium Levels and the Response to Tolvaptan in Liver Cirrhosis Patients with Ascites and Hyponatremia. Intern Med. 2018 Sep;57(17):2451-8.

12 Kawaratani H, Fukui H, Moriya K, Noguchi R, Namisaki T, Uejima M, et al. Predictive parameter of tolvaptan effectiveness in cirrhotic ascites. Hepatol Res. 2017 Aug;47(9): 854-61.
13 Liberati A, Altman DG, Tetzlaff J, Mulrow C, Gøtzsche PC, Ioannidis JP, et al. The PRISMA statement for reporting systematic reviews and meta-analyses of studies that evaluate health care interventions: explanation and elaboration. J Clin Epidemiol. 2009 Oct; 62(10):e1-34.

14 Sterne JA, Hernán MA, Reeves BC, Savović J, Berkman ND, Viswanathan M, et al. ROBINS-I: a tool for assessing risk of bias in nonrandomised studies of interventions. BMJ. 2016 Oct;355:i4919.

15 Higgins JP, Thompson SG, Deeks JJ, Altman DG. Measuring inconsistency in meta-analyses. BMJ. 2003 Sep;327(7414):557-60.

16 Tierney JF, Stewart LA, Ghersi D, Burdett S, Sydes MR. Practical methods for incorporating summary time-to-event data into metaanalysis. Trials. 2007 Jun;8(1):16.

17 Parmar MK, Torri V, Stewart L. Extracting summary statistics to perform meta-analyses of the published literature for survival endpoints. Stat Med. 1998 Dec;17(24):2815-34.

18 Williamson PR, Smith CT, Hutton JL, Marson AG. Aggregate data meta-analysis with time-to-event outcomes. Stat Med. 2002 Nov; 21(22):3337-51. 
19 Iwamoto T, Maeda M, Hisanaga T, Saeki I, Fujisawa K, Matsumoto T, et al. Predictors of the Effect of Tolvaptan on the Prognosis of Cirrhosis. Intern Med. 2016;55(20):2911-6.

20 Yamada T, Ohki T, Hayata Y, Karasawa Y, Kawamura S, Ito D, et al. Potential Effectiveness of Tolvaptan to Improve Ascites Unresponsive to Standard Diuretics and Overall Survival in Patients with Decompensated Liver Cirrhosis. Clin Drug Investig. 2016 Oct; 36(10):829-35.

21 Atsukawa M, Tsubota A, Kato K, Abe H, Shimada N, Asano T, et al. Analysis of factors predicting the response to tolvaptan in patients with liver cirrhosis and hepatic edema. J Gastroenterol Hepatol. 2018 Jun;33(6): 1256-63.

22 Kogiso T, Kobayashi M, Yamamoto K, Ikarashi Y, Kodama K, Taniai M, et al. The Outcome of Cirrhotic Patients with Ascites Is Improved by the Normalization of the Serum Sodium Level by Tolvaptan. Intern Med. 2017 Nov;56(22):2993-3001.

23 Tahara T, Mori K, Mochizuki M, Ishiyama R, Noda M, Hoshi $\mathrm{H}$, et al. Tolvaptan is effective in treating patients with refractory ascites due to cirrhosis. Biomed Rep. 2017 Dec;7(6):55862.

24 Arase Y, Kagawa T, Tsuruya K, Sato H, Teramura E, Anzai K, et al. Impaired Renal Function May Not Negate the Efficacy of Tolvap$\tan$ in the Treatment of Cirrhotic Patients with Refractory Ascites. Clin Drug Investig. 2019 Jan;39(1):45-54.

25 Tajiri K, Tokimitsu Y, Ito H, Atarashi Y, Kawai K, Minemura M, et al. Survival Benefit of Tolvaptan for Refractory Ascites in Patients with Advanced Cirrhosis. Dig Dis. 2018;36(4):314-21.

26 Wang S, Zhang X, Han T, Xie W, Li Y, Ma H, et al. Tolvaptan treatment improves survival of cirrhotic patients with ascites and hyponatremia. BMC Gastroenterol. 2018 Sep;18(1): 137.

27 Kida Y. Positive Response to Tolvaptan Treatment Would Be a Good Prognostic Factor for Cirrhotic Patients with Ascites. Dig Dis. 2019; 37(3):239-46.

28 Kogiso T, Yamamoto K, Kobayashi M, Ikarashi Y, Kodama K, Taniai M, et al. Response to tolvaptan and its effect on prognosis in cirrhotic patients with ascites. Hepatol Res. 2017 Aug;47(9):835-44.

29 Nakai M, Ogawa K, Takeda R, Ohara M, Kawagishi N, Izumi T, et al. Increased serum $\mathrm{C}$-reactive protein and decreased urinary aquaporin 2 levels are predictive of the efficacy of tolvaptan in patients with liver cirrhosis. Hepatol Res. 2018 Feb;48(3):E311-9.

30 Hiramine $\mathrm{Y}$, Uto $\mathrm{H}$, Mawatari S, Kanmura S, Imamura Y, Hiwaki T, et al.: ffect of Tolvaptan on the Prognosis in Patients with Hepatic Ascites. Hepatol Res. 2019 Jul;49(7):76577.

31 Fortune B, Cardenas A. Ascites, refractory ascites and hyponatremia in cirrhosis. Gastroenterol Rep (Oxf). 2017 May;5(2):104-12.

32 Wong F, Watson H, Gerbes A, Vilstrup H, Badalamenti S, Bernardi M, et al.; Satavaptan Investigators Group. Satavaptan for the management of ascites in cirrhosis: efficacy and safety across the spectrum of ascites severity. Gut. 2012 Jan;61(1):108-16.

33 Akiyama S, Ikeda K, Sezaki H, Fukushima T, Sorin Y, Kawamura Y, et al. Therapeutic effects of short- and intermediate-term tolvaptan administration for refractory ascites in patients with advanced liver cirrhosis. Hepatol Res. 2015 Nov;45(11):1062-70.

34 Cárdenas $\mathrm{A}$, Ginès $\mathrm{P}$, Marotta $\mathrm{P}$, Czerwiec $\mathrm{F}$, Oyuang J, Guevara M, et al. Tolvaptan, an oral vasopressin antagonist, in the treatment of hyponatremia in cirrhosis. J Hepatol. 2012 Mar;56(3):571-8.

35 Uojima H, Kinbara T, Hidaka H, Sung JH, Ichida $\mathrm{M}$, Tokoro $\mathrm{S}$, et al. Close correlation between urinary sodium excretion and response to tolvaptan in liver cirrhosis patients with ascites. Hepatol Res. 2017 Mar;47(3): E14-21.

36 Nakanishi H, Kurosaki M, Hosokawa T, Takahashi Y, Itakura J, Suzuki S, et al. Urinary excretion of the water channel aquaporin 2 correlated with the pharmacological effect of tolvaptan in cirrhotic patients with ascites. J Gastroenterol. 2016 Jun;51(6):620-7.

37 Yan L, Xie F, Lu J, Ni Q, Shi C, Tang C, et al. The treatment of vasopressin V2-receptor antagonists in cirrhosis patients with ascites: a meta-analysis of randomized controlled trials. BMC Gastroenterol. 2015 Jun;15(1):65.

38 Dahl E, Gluud LL, Kimer N, Krag A. Metaanalysis: the safety and efficacy of vaptans (tolvaptan, satavaptan and lixivaptan) in cirrhosis with ascites or hyponatraemia. Aliment Pharmacol Ther. 2012 Oct;36(7):619-26.

39 Torres VE, Chapman AB, Devuyst O, Gansevoort RT, Grantham JJ, Higashihara E, et al.; TEMPO 3:4 Trial Investigators. Tolvaptan in patients with autosomal dominant polycystic kidney disease. N Engl J Med. 2012 Dec; 367(25):2407-18.

40 Bellos I, Kontzoglou K, Perrea DN. Predictors of tolvaptan short-term response in patients with refractory ascites: A meta-analysis. J Gastroenterol Hepatol. 2019 Jul;jgh.14784.; Epub ahead of print.

41 Hinz M, Wree A, Jochum C, Bechmann LP, Saner F, Gerbes AL, et al.: High age and low sodium urine concentration are associated with poor survival in patients with hepatorenal syndrome. Ann Hepatol. 2013 Jan-Feb; 12(1):92-9. 